\title{
Urinsyregikt - nytt innen diagnostikk og behandling
}

\author{
Et anfall med urinsyregikt er svært smertefullt. Typisk for denne hyppige \\ tilstanden er tilbakevendende anfall med artritt i ett eller flere ledd- \\ områder eller seneskjeder med intens smerte. Da disse symptomene \\ tyder på akutt inflammasjon på grunn av avleirede urinsyrekrystaller, \\ er det viktig med god diagnostikk for å kunne starte medikamentell \\ behandling som fjerner krystaller avleiret i vevet.
}

Urinsyregikt er en inflammatorisk revmatisk sykdom der patofysiologien er ganske enkel sammenlignet med andre inflammatoriske revmatiske sykdommer. Behandlingen er ofte suboptimal, fordi den er rettet mot det akutte anfallet og ikke mot langtidsresultater - hvor målet er å kurere sykdommen (1).

Urinsyregikt er genetisk betinget, men også en del av det metabolske syndrom, forårsaket av moderne livsstil og ernæring. Metabolsk syndrom kan i vestlige samfunn ses hos opptil $2 \%$ av alle voksne (2). Dessuten øker hyppigheten av urinsyregikt med økende alder - og påvises dermed oftere på grunn av stadig lengre levetid. Nyresvikt forekommer oftere ved høy alder, ved bruk av urinsyreøkende diuretika og ved komorbiditet. Nye undersøkelser fra Storbritannia viser at hos mennesker over 75 år er prevalensen av urinsyregikt på $7 \%$ hos menn og på $4 \%$ hos kvinner (3).

Diagnostikk og behandling av urinsyregikt er en oppgave for alle leger, men først og fremst fastleger og revmatologer. De siste årene har det skjedd en stor utvikling med forbedringer innen diagnostikk og behandling av urinsyregikt: etablering av nye klassifikasjonskriterier, forbedret bildediagnostikk med bruk av ultralyd og computertomografi (Dual Energy Computer Tomography, DECT), det er kommet nye medikamenter som kan senke urinsyrenivået i serum og biologiske medikamenter som motvirker inflammasjonen.

I denne artikkelen gis en oversikt over nytt innen diagnostikk og behandling, basert på et skjønnsmessig litteraturutvalg.

\section{Patofysiologi}

Urinsyre (urat) er sluttproduktet av purinmetabolismen. Avgjørende er nøkkelenzymet xantinoksidase, som metaboliserer xantin og hypoxantin. Vanligvis er urinsyren løst opp i serum ved vanlig kroppstemperatur og $\mathrm{pH} 7,4$, men over en løselighetsgrense på $360 \mu \mathrm{mol} / 1$ skjer det imidlertid en utfelling av mononatriumkrystaller i vevet. Faren for anfall med urinsyregikt er avhengig av urinsyrenivået og er økt ved verdier over $420-450 \mu \mathrm{mol} / \mathrm{l}$. Av leddene er det først og fremst stortåens grunnledd, forføtter og ankler som blir angrepet, men også $\mathrm{i}$ andre ledd samt $\mathrm{i}$ sener og bursaer kan man finne utfellinger.

Urinsyren skilles ut i nyrene, og hyperurikemi er assosiert med redusert nyrefunksjon, men danning av uratsten kan forekomme på grunn av lokal utkrystallisering av urinsyre. De renale transportsystemene spiller en viktig rolle. For eksempel koder SCL22A12-genet (også kalt for URAT1) for et transportprotein som kontrollerer uratreabsorpsjonen i proksimale tubulus og som kan påvirkes av farmakologiske substanser som probenecid, lesinurad, benzbromaron og losartan (4). SCK2A9 (GLUT9) er en transportør for fruktose og urat.

De siste årene er det funnet en rekke gener som er assosiert med høye urinsyrenivåer $\mathrm{i}$ serum og med urinsyregikt $(5,6)$. Den utvidede forståelsen av mekanismene i uratsystemet fører til nye angrepspunkter for farmakologiske substanser, der målet er å øke utskillingen av urinsyre gjennom nyrene.

\section{Klinisk diagnostikk}

Hyppigst manifesterer urinsyregikt seg som artritt $i$ ett ledd. Klassisk er anfall $i$ grunnleddet til første tå (MTP1), kalt podagra. Noen ganger manifester urinsyregikt seg oligoartikulært (2-4 ledd) eller polyartikulært (mer enn fire ledd). Vanligvis er anfallene episodiske, det kan gå måneder og år uten symptomer.

I de nye klassifikasjonskriteriene beskrives det at smerten typisk øker til et maksimum innen 24 timer og at de sterke smertene varer en uke - før området som regel blir fullstendig symptomfritt etter ca. 14 dager.

I den kliniske hverdag kan tidlige krystallavleieringer påvises ved hjelp av ultralydundersøkelser av leddene. Hvis urinsyregikt er en mulig differensialdiagnose, bør leddet punkteres for å kunne påvise urinsyrekrystaller og dermed sikre diagnosen. Leddvæsken undersøkes i polarisert lys. Ved urinsyregikt

\section{Till Uhlig}

tillmann.uhlig@medisin.uio.no

Nasjonal kompetansetjeneste for revmatologisk rehabilitering

Revmatologisk avdeling

Diakonhjemmet Sykehus

\section{Tron Eskild}

Radiologisk avdeling

Diakonhjemmet Sykehus

Hilde Berner Hammer

Revmatologisk avdeling

Diakonhjemmet Sykehus

\section{HOVEDBUDSKAP}

Gullstandard for diagnostikk er påvisning av urinsyrekrystaller ved polarisasjonsmikroskopi, men symptombeskrivelse og supplerende bildediagnostikk kan sannsynliggjøre diagnosen

I tillegg til allopurinol og kolkisin er det kommet nye medikamenter som hemmer xantinoksydase og interleukin-1 eller fremmer utskilling av urinsyre gjennom nyrene

For å forebygge nye anfall av urinsyregikt bør urinsyrenivået være under $360 \mu \mathrm{mol} / \mathrm{l}$

Ultralydundersøkelse og DECT-undersøkelse (Dual Energy Computer Tomography) kan anvendes til diagnostikk og kontroll 


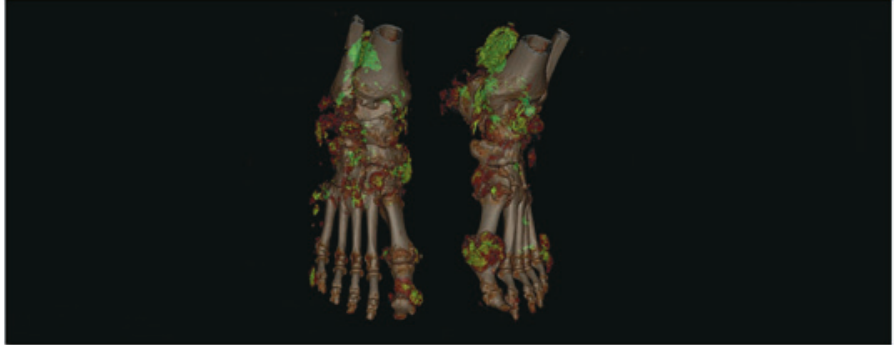

a

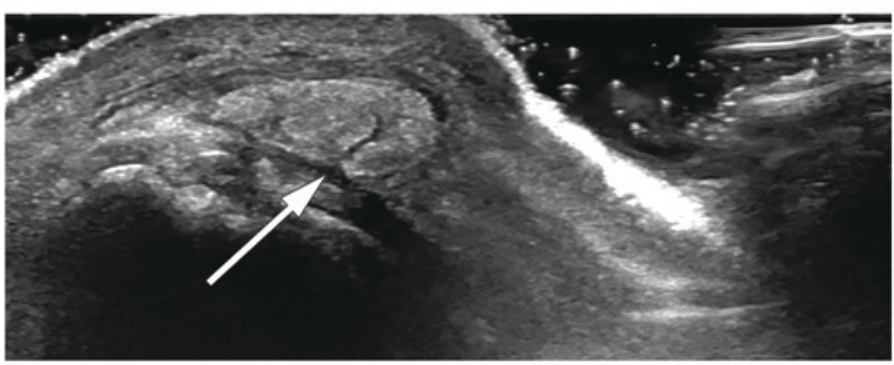

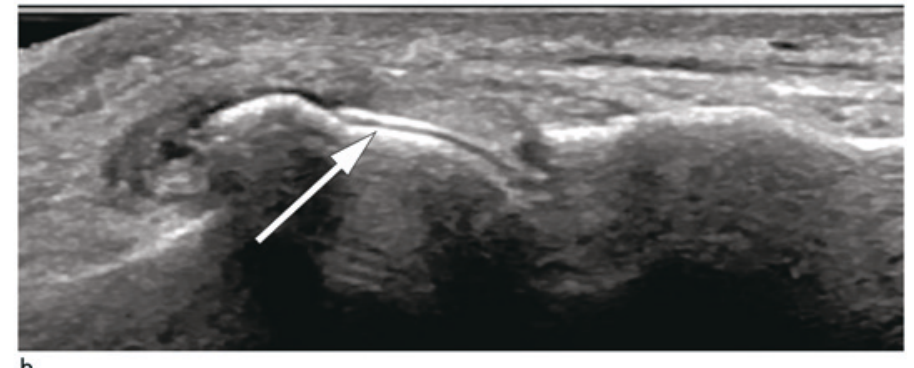
$b$

Figur 1 a) DECT-undersøkelse som viser uratavleiringeriankler og føtter samt langs akillessener. b) Ultralydbilde av tåledd med avleiring av urat, som visualiseres som dobbeltkontur lavleiringer av urinsyrekrystaller oppå bruskoverflaten). c) Urinsyreavleiring i form av en tophus lokalisert subkutant på håndens dorsalside påvises dobbelt lysbrytende intra- og ekstracelluært beliggende nåleformede krystaller i polarisasjonsmikroskopet. Pasienten må også undersøkes for tilstedeværelse av tophi. Etter at diagnosen er stilt, bør man lete etter komorbiditet, slik som arteriell hypertensjon, nyresvikt, hjertesvikt, diabetes eller hyperlipemi.

\section{Nye klassifikasjonskriterier}

I alle år har påvisning av urinsyrekrystaller vært gullstandarden for diagnostikk og klassifisering av urinsyregikt. Siden tapping av leddvæske sjelden utføres i allmennpraksis, er det $\mathrm{i}$ Nederland foreslått et skåringssystem for diagnostikk av urinsyregikt i allmennpraksis
(7). Det er basert på et enkelt poengsystem som tar hensyn til kjønn, leddlokalisering, anfallsmønster og nivå av urinsyre i serum.

Det har vært en rekke forsøk på å etablere kriterier med høy sensitivitet og spesifisitet. Ved undersøkelse av de foreslåtte klassifikasjonskriteriene i en stor internasjonal kohort (med inklusjon av norske pasienter) fant man at sensitiviteten var best ved etablert sykdom $(95,3 \%)$ og at spesifisiteten var best ved tidlig sykdom (79,9\%) (8). For kriterier som ikke krevde analyse av synovial leddvæske var både spesifisiteten og sensitiviteten under $80 \%$, og det ble spesielt etterlyst kriterier med bedre spesifisitet.
Høsten 2015 kom det nye klassifikasjonskriterier for urinsyregikt (9). Disse støttes av de amerikanske og europeiske revmatologforeningene (ACR/EULAR-kriteriene) (9). Disse kriteriene har sensitivitet og en spesifisitet på ca. $90 \%$.

Inngangsporten til evalueringen er at det er minst én episode med hevelse, smerte eller ømhet $\mathrm{i}$ et perifert ledd- eller bursaområde. Ved påvisning av uratkrystaller fra synovialvæske er klassifikasjonskravene allerede tilfredsstilt. Men også ved negative funn under mikroskopering vil bruk av skåringsalgoritme (dog med fratrekk av poeng i tilfelle negativ mikroskopi eller meget lavt serum-

Tabell 1 Nye ACR/EULAR-klassifikasjonskriterier ved urinsyregikt. Det trengs 8 poeng for å tilfredsstille kriteriene

\begin{tabular}{|c|c|c|}
\hline Domene & Spesifikke funn & Poeng (maksimalt 23) \\
\hline Leddmønster & $\begin{array}{l}\text { Ankel/forfot } \\
\text { Stortåens grunnledd (MTP1) }\end{array}$ & $\begin{array}{l}1 \\
2\end{array}$ \\
\hline Kjennetegn for episoden & $\begin{array}{l}\text { Erytem over leddet } \\
\text { Svært smertefullt ved berøring/trykk } \\
\text { Store vansker med å gå/bruke leddet }\end{array}$ & Maksimalt 3 \\
\hline Tidsforløp ved anfall & $\begin{array}{l}\text { Maksimal smerte nådd i løpet av } 24 \text { timer } \\
\text { Tilbakegang av symptomene innen } 14 \text { dager } \\
\text { Fullstendig tilbakegang }\end{array}$ & $\begin{array}{l}1 \text { (minst } 2 \text { funn oppfylt ved en typisk episode) } \\
2 \text { (minst } 2 \text { funn oppfylt ved gjentatte episoder) }\end{array}$ \\
\hline Klinisk tophus & Til stede & 4 \\
\hline Urinsyrenivå (mellom anfall) & $\begin{array}{l}<240 \mu \mathrm{mol} / \mathrm{l} \\
360-<480 \mu \mathrm{mol} / \mathrm{l} \\
480-<600 \mu \mathrm{mol} / \mathrm{l} \\
\geq 600 \mu \mathrm{mol} / \mathrm{l}\end{array}$ & $\begin{array}{l}-4 \\
2 \\
3 \\
4\end{array}$ \\
\hline Uratkrystaller ved utført aspirasjon av leddvæske & Leddvæske negativ for uratkrystaller & -2 \\
\hline Bildediagnostikk & Ultralyd- eller DECT-positiv & 4 \\
\hline Konvensjonell radiografi & Typisk erosjon & 4 \\
\hline
\end{tabular}


urinsyrenivå) kunne bidra til en urinsyregiktdiagnose. Dette er et vesentlig fremskritt. Kliniske funn som vektes og inngår i skåringen er vist $\mathrm{i}$ tabell 1 og illustrerer typiske symptomer ved urinsyregikt.

\section{Bildediagnostikk}

\section{Ultralydundersøkelse}

Ultralydundersøkelse brukes i økende grad av revmatologer for å diagnostisere forskjellige degenerative og inflammatoriske revmatiske sykdommer. Ved et internasjonalt samarbeid er det nå identifisert fire ultralydforandringer som angis å være typiske for urinsyregikt (10).

Dobbelkontur. En hyperekkoisk linje på overflaten av brusken reflekterer massiv avleiring av urinsyrekrystaller. Konturen er diagnostisk når den påvises på bruskoverflaten $\mathrm{i}$ en vinkel som ikke er $90^{\circ}$ på ultralydproben (dvs. ikke vanlig bruskrefleksjon). Konturen har typisk samme tykkelse som konturen av benoverflaten, derav navnet dobbeltkontur (som dannes av en hyperekkoisk (hvit) benoverflate over den en anekkoisk (svart) brusk og øverst en hyperekkoisk (hvit) urinsyrekrystallavleiring på bruskens overflate) (fig 1).

Tophus. En tett samling av urinsyrekrystaller som kan ses inne $i$ et ledd, inne $i$ en sene eller seneskjede, subkutant eller i øvrig vev. Disse avleiringene kan være myke, dvs. man kan se bevegelsene til urinsyrekrystallene inne i tophus ved palpasjon, eller harde, dvs. med forkalkninger som gir slagskygge. Størrelsen varierer fra millimeterstore til flere centimeter store (fig 1).

Erosjoner. Skade på benet på grunn av den hissige inflammatoriske aktiviteten under urinsyregiktanfallene. Hvis det er en viss størrelse på erosjonene, kan de også ses på røntgen som typiske «billettklipp».

Aggregater. Dette er mindre avleiringer av urinsyrekrystaller i ledd, sener, bursaer eller andre steder. Man ser små hyperekkoiske forandringer, men de er ikke nødvendigvis diagnostiske for urinsyregikt, da også annet patologisk kan gi samme bilde.

Påvisning av dobbelkontur og tophus vil være diagnostisk for urinsyregikt, selv om påvisning av urinsyrekrystaller er ønskelig ved leddpunksjon (som kan utføres ultralydveiledet for bedre muligheten til å aspirere krystallholdig væske/vev).

\section{DECT-undersøkelse}

DECT-undersøkelse supplerer ikke-invasive metoder ved å gi farger til materialer med kjemisk forskjellig komposisjon (11). CTskanneren bruker to forskjellige spenninger, vanligvis $80 \mathrm{kV}$ og $140 \mathrm{kV}$. Etter bearbeiding av data kan urinsyrekrystaller/tophi skilles fra ben, bløtdelsvev og hydroksyapatitt og visualiseres (fig 1). Denne metoden er relativt ny og fungerer best ved etablert sykdom med en viss mengde avleiring av krystaller.
Metoden er tilgjengelig ved en rekke norske sykehus og kan dermed ha sin plass når diagnosen ikke er sikker eller når man ønsker å evaluere om effektiv behandling har redusert mengden av/størrelsen på tophi.

\section{Nye medikamenter}

Allopurinol, som er et godt kjent medikament, er førstevalg i behandlingen for å senke urinsyrenivået i blodet. Som xantinoksidasehemmer påvirker dette midlet metaboliseringen av purin fra kostholdet og gir redusert danning av urinsyre. Tidligere startet man med allopurinol først når pasienten hadde hatt flere anfall. I den senere tid er det blitt hevdet at oppstart med allopurinol kanskje bør gjennomføres allerede ved første anfall (12) og uten å vente til det akutte anfallet med urinsyregikt er gått helt over. Ved eventuelt senere anfall bør allopurinolbehandlingen ikke avbrytes under anfallsperioden.

Allopurinoldosen er vanligvis $100 \mathrm{mg}$ daglig initialt og økes med $100 \mathrm{mg}$ månedlig. Mange pasienter får for lave doser, da opptil 600-900 mg/døgn kan være nødvendig. All dosering styres etter måloppnåelse på $<360$ $\mu \mathrm{mol} / \mathrm{l}$ urinsyre i serum (eller $<300 \mu \mathrm{mol} / 1$ hvis påvist tophi). Over tid vil da de avleirede krystallene løses opp og urinsyren skilles ut via nyrene. Når det ikke lenger er urinsyrekrystallavleiringer av betydning, vil nye anfall ikke kunne forekomme.

Febuxostat er en relativ ny selektiv xantinoksidasehemmer og et alternativ ved manglende effekt av eller intoleranse for allopurinol, men særskilt forsiktighet anbefales foreløpig hos pasienter med iskemisk hjertesykdom eller hjertesvikt (13).

Siden det i studier er observert økt risiko for nye anfall etter innledning av urinsyrenedsettende behandling, bør pasienten etter nye anbefalinger få forebyggende behandling med kolkisin eller ikke-steroide antiflogistika i opptil seks måneder etter oppstart av allopurinol eller febuxostat.

Siste tilskudd i behandlingen er et medikament som gir økt sekresjon av urinsyre gjennom selektiv hemming av urattransportør 1 (URAT1) og som kombineres med en xantinoksidasehemmer. Dette virkestoffet, lesinurad, er nylig blitt godkjent av de europeiske legemiddelmyndighetene (EMA). Det bidrar til at urinsyrenivået senkes - det skjer både ved hemming av syntesen og ved samtidig økt utskilling gjennom nyrene.

Biologiske medikamenter (interleukin-1hemmere), som brukes ved inflammatoriske tilstander innen revmatologi, hudsykdommer og gastroenterologi, har også vist effekt ved urinsyregikt ved å hemme inflammasjonen under et akutt anfall samt forebygge nye anfall.

Erfaringsmessig har anakinra, en interleukin-1-hemmer som er registrert for revmatoid artritt, god effekt mot inflammasjon og smerter ved urinsyregikt ved korttidsbehandling (14). Midlet er relativt rimelig for korttidsbehandling, men er ikke registrert for denne sykdommen. Kanakinumab er en interleukin$1 \beta$-hemmer med effekt ved behandlingsrefraktær urinsyregikt. Imidlertid begrenser kostnaden for dette medikamentet (> 100000 kroner for én injeksjon) bruken i stor grad. Dette gjelder også behandling med peglotikase, en rekombinant form av urikase, som katalyserer overgangen fra urinsyre til allantoin.

Dersom prisen for de biologiske medikamentene blir akseptabel, vil disse kunne være til stor hjelp som anfallsbehandling ved refraktær urinsyregikt.

\section{Konklusjon}

Urinsyregikt er en såpass hyppig sykdom at leger bør ha god kunnskap om den. I moderne diagnostikk av urinsyregikt er direkte påvisning av urinsyrekrystaller viktig. Imidlertid er ultralyd- og DECT-undersøkelse blitt viktige hjelpemidler for å påvise uratkrystaller når diagnosen ikke er sikret.

Viktig i behandlingen er tidlig bruk av medikamenter som reduser serum-urinsyrenivået til under $360 \mu \mathrm{mol} / 1$, slik at risikoen for nye, smertefulle anfall på grunn av urinsyreutfelling i vevet praktisk talt elimineres.

\section{Till Uhlig (f. 1960)}

er spesialist i revmatologi, seksjonsoverlege og professor ved Universitetet i Oslo.

Forfatter har fylt ut ICMJE-skjemaet og oppgir følgende interessekonflikter: Han har mottatt bidrag fra AstraZeneca og Novartis.

\section{Trond Eskild (f. 1958)}

er spesialist i radiologi og overlege. Forfatter har fylt ut ICMJE-skjemaet og oppgir ingen interessekonflikter.

\section{Hilde Berner Hammer (f. 1958)}

er revmatolog, med spesialkompetanse innen ultralyd. Hun er assisterende avdelingssjef for Revmatologisk avdeling

Forfatter har fylt ut ICMJE-skjemaet og oppgir følgende interessekonflikter: Hun har mottatt foredragshonorar og/eller bidrag fra AbbVie, BMS, Pfizer, UCB, Roche, MSD og Novartis.

\footnotetext{
Litteratur

1. Doherty M, Jansen TL, Nuki G et al. Gout: why is this curable disease so seldom cured? Ann Rheum Dis 2012; 71: 1765-70.

2. Annemans L, Spaepen E, Gaskin M et al. Gout in the UK and Germany: prevalence, comorbidities and management in general practice 2000-2005. Ann Rheum Dis 2008; 67: 960-6
} 
3. Kuo CF, Grainge MJ, Mallen $C$ et al. Rising burden of gout in the UK but continuing suboptimal management: a nationwide population study. Ann Rheum Dis 2015; 74: 661-7.

4. Uhlig T. Urinsyregikt og hyperurikemi - skal begge deler behandles? Tidsskr Nor Lægeforen 2003; 123: $2878-80$.

5. Merriman TR, Choi HK, Dalbeth N. The genetic basis of gout. Rheum Dis Clin North Am 2014; 40 : 279-90.

6. Reginato AM, Mount DB, Yang I et al. The genetics of hyperuricaemia and gout. Nat Rev Rheumatol 2012; 8: 610-21.

7. Janssens HJ, Fransen J, van de Lisdonk EH et al. A diagnostic rule for acute gouty arthritis in primary care without joint fluid analysis. Arch Intern Med 2010; 170: 1120-6.

8. Taylor WJ, Fransen J, Dalbeth $\mathrm{N}$ et al. Performance of classification criteria for gout in early and established disease. Ann Rheum Dis 2016; 75 : $178-82$

9. Neogi T, Jansen TL, Dalbeth N et al. 2015 Gout classification criteria: an American College of Rheumatology/European League Against Rheumatism collaborative initiative. Ann Rheum Dis 2015; 74: 1789-98.

10. Terslev L, Gutierrez M, Schmidt WA et al. Ultrasound as an Outcome Measure in Gout. A Validation Process by the OMERACT Ultrasound Working Group. J Rheumatol 2015; 42: 2177-81.

11. Choi HK, Al-Arfaj AM, Eftekhari A et al. Dual energy computed tomography in tophaceous gout. Ann Rheum Dis 2009; 68: 1609-12.

12. Taylor TH, Mecchella JN, Larson RJ et al. Initiation of allopurinol at first medical contact for acute attacks of gout: a randomized clinical trial. Am J Med 2012; 125: 1126-1134.e7.

13. Jansen TL, Richette P, Perez-Ruiz F et al. International position paper on febuxostat. Clin Rheumatol 2010; 29: 835-40

14. Ottaviani S, Moltó A, Ea HK et al. Efficacy of anakinra in gouty arthritis: a retrospective study of 40 cases. Arthritis Res Ther 2013; 15: R123.

Mottatt 16.2. 2016, første versjon innsendt 15.8 .

2016, godkjent 22.8. 2016. Redaktør: Tor Rosness. 